\title{
The Effect of Stimulants and Environmental Factors on Resin Yield of Pinus merkusii Tapping
}

\author{
Ganis Lukmandaru,* Syaiful Amri, Sigit Sunarta, Tomy Listyanto, Rini Pujiarti, and \\ Ragil Widyorini
}

\begin{abstract}
Oleoresin from Pinus merkusii is one of the most important forest products in Indonesia. The objective of this study was to examine the effects of various stimulants and environmental factors on oleoresin yield. The first factor was the stimulant treatment, i.e., SAEt1 (20\% sulfuric acid $+1 \%$ Ethephon); SAEt2 (20\% sulfuric acid $+2 \%$ Ethephon); SR4 (mainly composed by sulfuric acid); ETRAT (mainly composed by ethylene and citric acid); and without stimulant spraying. The second factor was the site with different altitudes, i.e., West Banyumas (326 m asl), East Banyumas (797 m asl), and West Pekalongan (1150 m asl). Through analysis of variance, the relation between stimulant and site was highly significant in regards to the average daily oleoresin yield. The results indicated that the combination of sulfuric acid and Ethephon increased oleoresin production 1.69- to 2.85-fold compared with untreated trees, depending on the sites. The trees with SAEt1 and SAEt2 treatments yielded an equivalent amount of oleoresin compared to that of trees exposed to the SR4. The ETRAT showed the lowest resin yields compared to the other stimulants. The values of daily relative humidity and temperature did not show similar responses in all sites when correlated with daily oleoresin yield.
\end{abstract}

Keywords: Oleoresin exudation; Altitude; Quarre; Perhutani; Stimulant; Resin production; Pinus merkusii

Contact information: Department of Forest Products Technology, Faculty of Forestry, Universitas Gadjah Mada, Jl. Agro No.1, Bulaksumur, Sleman 55281, Indonesia +6274 550541;

*Corresponding author: glukmandaru@ugm.ac.id

\section{INTRODUCTION}

Pinus merkusii Jungh. Et De Vriese is one of the most important timbers and the primary species commercially tapped for oleoresin in Indonesia. The species has been planted in the island of Java by Perhutani (a state-owned enterprise). Wordwide, Indonesia is third place, after China and Brazil, in average pine resin production, equaling 90,000 tons per year (Perhutani 2017).

The total stand under pine forests is estimated to be 877,330 ha and located between $200 \mathrm{~m}$ and $2000 \mathrm{~m}$ altitude (Hendromono et al. 2006). Further, the pine trees that grow in stands with high average rainfall, cold temperature, or in stands with a height $>700 \mathrm{~m}$ asl produce less resin; whereas higher resin yields are associated with the trees that grow in stands with average rainfall of $<2,000 \mathrm{~mm}$ /year, temperatures between 22 to $28{ }^{\circ} \mathrm{C}$, and 400 to $700 \mathrm{~m}$ asl (Perhutani 2017). Environmental factors affect the oleoresin yield in several pines (Rodriguez-Garcia et al. 2015; Bhardwaj et al. 2017; Gajsek et al. 2018; Sharma et al. 2018). However, the studies with regard to the effect of environmental factors on oleoresin yield of Pinus merkusii remain limited. Previous works have reported that the oleoresin yield of pines was also strongly influenced by genenetic factor (Mergen et al. 1955; Tadesse et al. 2001; Siregar and Hatemer 2004). 
To increase the production of pine resin by tapping, Perhutani has introduced the use of several commercial stimulants containing sulfuric acid, ethephon, and citric acid. Unfortunately, those stimulants did not work satisfactorily and were applied only in certain stands (Sukadaryati et al. 2014; Darmastuti et al. 2016; Lempang 2017). Natural or biostimulant agents were also tried in a $P$. merkusii stand from Perhutani site (Sukadaryati and Dulsalam 2013). Furthermore, local people employed by Perhutani also used aqueous sulphuric acid in a high concentration to increase oleo-resin yield, which could cause deleterious effects during the economic life of pine trees. Therefore, a more effective use of stimulating agents should be sought to increase the oleoresin yield in larger stands.

To increase resin flux and extend the extruding period, ethephone (ethrel, 2chloroethylphosphonic acid, CEPA), an ethylene precursor, was applied not only in other wounded pine trees (Wolter and Zinkel 1984; Rodrigues et al. 2008; Sharma and Lekha 2013), but also in latex (She et al. 2013) and gum exudates (Vasishth and Guleria 2017). However, Ethephon is expensive and the rational use of this stimulant should be investigated. In a previous study, the combination of sulfuric acid and Ethephon as the stimulating agents proved to be more effective than sulfuric acid alone in low and high concentrations (Lukmandaru et al. 2018). Due to the environmental and economical concerns, this study aimed to evaluate the use of stimulants containing comparatively low concentrations of sulfuric acid and Ethephon mixture in widened stands. Another objective was to explore the daily oleoresin yield and relate it with the daily temperature and relative humidity levels.

\section{EXPERIMENTAL}

\section{Materials}

Sites and tree samples

The oleoresin tapping was conducted in the rainy season during November 2015. The field experiments were conducted at three homogenous $P$. merkusii stands managed by Perhutani in the province of Central Java, i.e., Lumbir: West Banyumas Forest Management Unit (FMU; $326 \mathrm{~m}$ asl, 36 to 40 years, diameter breast height 20.3 to 84.6 cm, $2227 \mathrm{~mm}$ annual rainfall), Pandanarum, East Banyumas FMU (797 m asl, 31 to 35 years, diameter breast height 54.4 to $65.9 \mathrm{~cm}, 2157 \mathrm{~mm}$ annual rainfall), and Dukuh Tengah, West Pekalongan FMU (1150 m asl, 26 to 30 years, diameter breast height 22.6$42.0 \mathrm{~cm}, 216 \mathrm{~mm}$ annual rainfall). This represented three latitudinal clines, i.e., up to 400 $\mathrm{m}, 401$ to $800 \mathrm{~m}$, and 801 to $1200 \mathrm{~m}$. For more representative samplings, the environmental factors (daily temperature, relative humidity, and rainfall) as well as tree conditions were observed for a week before tapping operation. All trees used in the study had been tapped for resin prior to the experiments and randomly selected in the inner portion of the forest. The planting density was $3 \mathrm{~m} \times 2 \mathrm{~m}$.

\section{Stimulants preparation}

To increase the oleoresin flow from the trees, two different ratios of mixture of sulfuric acid $\left(\mathrm{H}_{2} \mathrm{SO}_{4}\right)$ (technical grade, concentration of 98\%; MKR Chemicals, Semarang, Indonesia) and Ethephon (concentration of $10 \mathrm{mg} / 100 \mathrm{~mL}$; PT Indobiotech Agro, Malang, Indonesia) were used as the stimulants. On the basis of the preliminary experiments (Lukmandaru et al. 2018), it was found that the mixture of $20 \%$ sulfuric acid - $2 \%$ Ethephon gave the highest yield in East Banyumas stand (class age of 16-20 years). In addition, SR4 
(100\%) showed no significant difference relative to those of $20 \%$ sulfuric acid - $2 \%$ Ethephon, whereas ETRAT $(100 \%)$ gave lower yields. The mixture in aqueous solution (v/v) was tested in two concentrations: sulfuric acid 20\%-Ethephon 1\% (SAEt1) and sulfuric acid 20\%-Ethephon 2\% (SAEt2). The current used stimulant solution provided by Perhutani, i.e., SR4 (unknown concentration of sulfuric acid as the active compound) and ETRAT (unknown concentration of ethylene and citric acid as the active compounds) were also tested as the positive controls as well as no stimulant spraying as the negative control.

\section{Methods}

\section{Resin tapping operation}

Resin tapping was performed using the bark chipping (quarre) method. On each selected tree, one wound $(20.0 \mathrm{~cm}$ high, $2.5 \mathrm{~cm}$ wide, and $6 \mathrm{~cm}$ thick) of the sapwood surface was made with a tapping tool. Then, the trees were subjected to two more tappings and stimulated again under the same conditions, i.e., same depth, height, and direction. The first wound was at $1.3 \mathrm{~m}$ above the ground (first period, day 1 through 6), then the second (second period, day 7 through 12), and the third wounds (third period, day 13 through 18) were at a slightly higher position. A metal and plastic sheet was fixed in the wound to minimize contamination in the exuded resin by foreign materials and rain water. Stimulant spraying was applied on the freshly wounded tissue with a spray bottle with a nozzle ( 2 to $3 \mathrm{~mL}$ per wound). The accumulated resin flow from each tree was collected in an open plastic cup placed at the base of the wounds and weighed on a field digital balance after careful draining of rain water everyday for a total of 18 days observation. The installation is shown in Fig. 1. The resin production for each tree was combined and averaged to obtain the daily oleoresin yield (DOY). Each tree was considered as a replication, and 20 replications were maintained for each treatment. For the yield variation analysis, along with daily oleoresin yield, the daily temperature and relative humidity were also measured from 10:00 to $11: 00$ a.m.

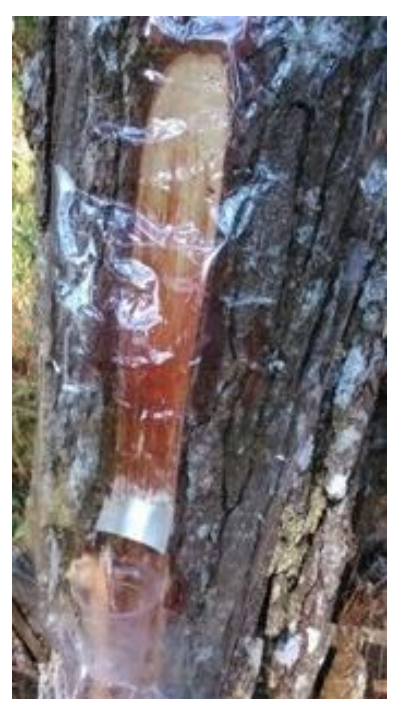

Fig. 1. Collection of oleoresin by bark chipping (quarre) method

\section{Statistical analysis}

The experimental design was a two factorial, randomized complete design with 20 replications. The first factor comprised five treatments of tapping. The second factor was 
sites of different altitude tested in three levels. Two-way analyses of variance (ANOVA) followed by Duncan multiple range test were used for data evaluation. To assess the correlation between DOY and its daily temperature or relative humidity, Pearson's correlation was used. The values of DOY were correlated with the values of daily temperature or relative humidity at the previous day. All computations were performed with IBM SPSS Statistics software (IBM Corporation, v.20, Armonk, NY, USA).

\section{RESULTS AND DISCUSSIONS}

\section{Pattern of Oleoresin Yield}

The daily observation results from the average of 20 trees in each treatment are presented in Fig. 2. The first day after wounding showed the highest yield both for the treated and control trees. After that, it decreased sharply at the second or third day and gradually reached its minimum value at the $6^{\text {th }}$ day (in first period). This same pattern was observed after re-wound and the stimulant re-spray to the tapping, the $7^{\text {th }}$ and $13^{\text {th }}$ day gave a higher yield of oleoresin production.
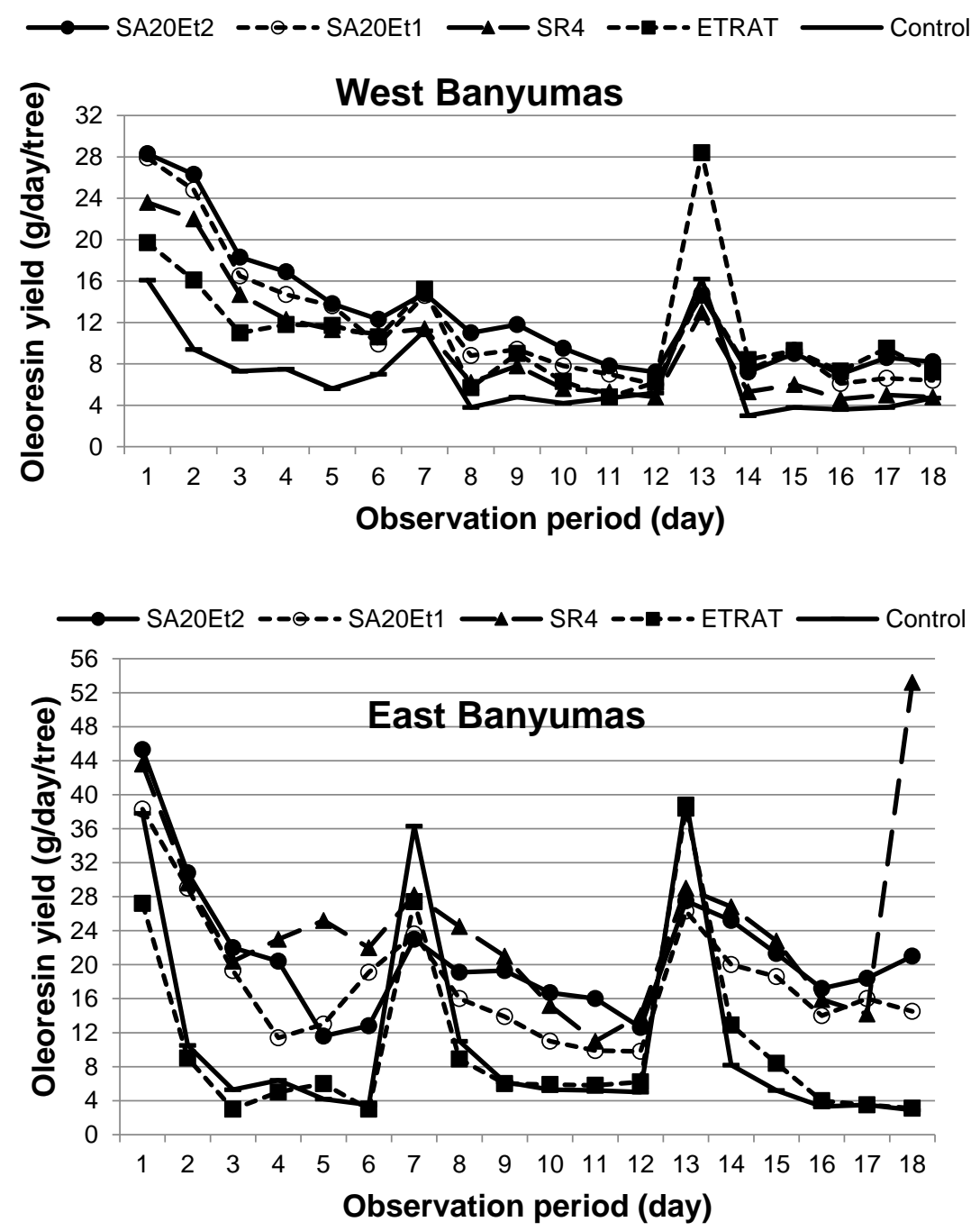


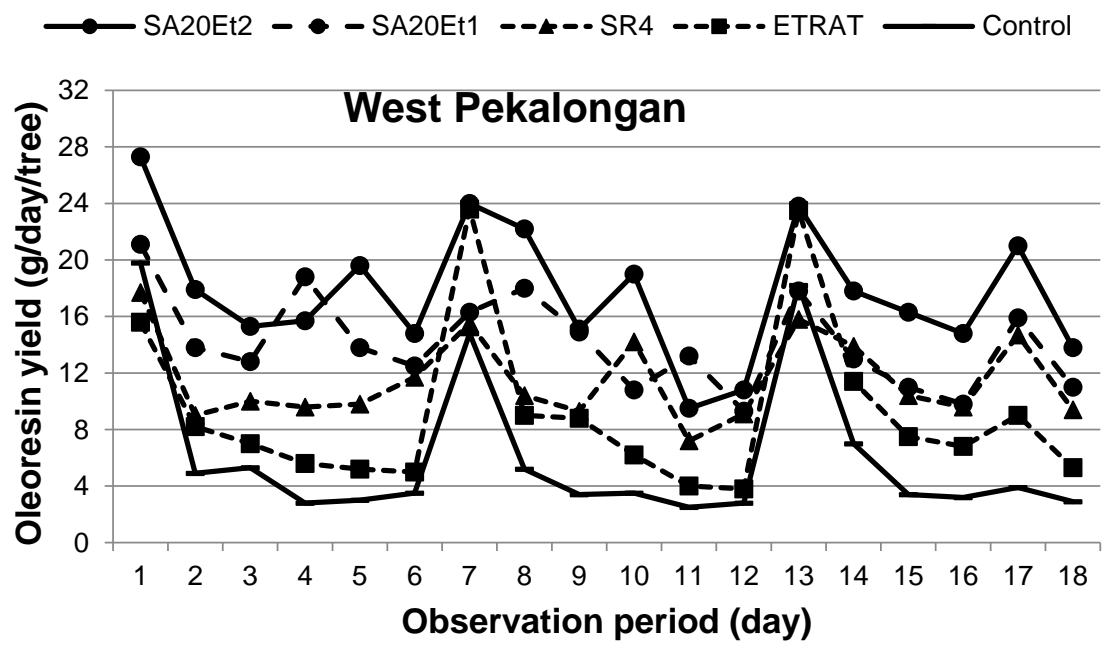

Fig. 2. Oleoresin yield exuded from one hole based in different stimulants and sites for the 18-day observation (average of 20 trees)

In general, the ETRAT-treated and the control trees yielded low contents of oleoresin, which was clearly shown in the East Banyumas and West Pekalongan stands. The yield obtained from SAEt2- and SAEt1-treated trees was higher than that from other stimulants in West Pekalongan stand, except that SR4 gave a slightly higher yield than that with SAEt 2 and SAEt1 in the East Banyumas stand.

In the field tapping practice, re-wound time is 4 to 6 days. In this study, the treatment was conducted three times for every six days. From daily observation, the yield reductions of trees submitted to the ETRAT and the control in the $2^{\text {nd }}$ or $3^{\text {rd }}$ day were 33 to $73 \%$ on the basis of the first day yield in West Banyumas, 73 to $89 \%$ in East Banyumas, and 56 to $82 \%$ in West Pekalongan stands. In contrast, the yield reductions were 22 to $42 \%$ in West Banyumas, 18 to $51 \%$ in East Banyumas, and 14 to $43 \%$ in West Pekalongan stands for SAEt2 and SAEt1 stimulated trees. The first period of tapping had slightly higher oleoresin production compared to that of the second and third period, particularly in the East Banyumas stand. Although only in a slight difference, the increasing yield was observed at the $17^{\text {th }}$ day for all treatments in the West Pekalongan stand. In addition, considerable increase of oleoresin production of the ETRAT-treated trees was observed after re-wound and re-spray at the $12^{\text {th }}$ day in the West Banyumas stand. The same trend was also found for the SR4 treatment at the $18^{\text {th }}$ day in the East Banyumas stand.

\section{Correlation between Oleoresin Yield and Environmental Factors}

The ranges of daily temperature and relative humidity measured at 10 to 11 a.m. were 23 to $31{ }^{\circ} \mathrm{C}$ and 46 to $99 \%$, respectively (Table 1). The abnormally high values of relative humidity were recorded on rainy days. Correlation between the yield and temperature or relative humidity is presented in Table 1. No significant correlation between yield and temperature or relative humidity in the control trees was found. However, the temperature was positively correlated ( $r=0.66$ to 0.68$)$ with yield from SAEt2, SAEt1, and SR4 treatments in the West Banyumas stand. Further, the relative humidity was negatively correlated with yield from East Banyumas (SAEt2 and SAEt1) and West Banyumas (SAEt2, SAEt1, and SR4) stands. 
Table 1. Daily Temperature and Relative Humidity Based in Sites for 18-dayobservation

\begin{tabular}{ccccccc}
\hline \multirow{2}{*}{$\begin{array}{c}\text { Observation } \\
\text { day }\end{array}$} & \multicolumn{3}{c}{ Relative humidity $(\%)$} & \multicolumn{3}{c}{ Temperature $\left({ }^{\circ} \mathrm{C}\right)$} \\
\cline { 2 - 7 } & EB & WB & WP & EB & WB & WP \\
\hline 0 & 78 & 46 & 72 & 27.1 & 27.4 & 27.3 \\
1 & 79 & 62 & 80 & 27.0 & 25.2 & 27.4 \\
2 & 79 & 97 & 74 & 26.8 & 26.2 & 27.7 \\
3 & 78 & 98 & 75 & 27.2 & 24.3 & 27.5 \\
4 & 81 & 91 & 66 & 26.9 & 23.6 & 26.5 \\
5 & 97 & 99 & 76 & 26.0 & 23.4 & 26.1 \\
6 & 97 & 99 & 80 & 24.8 & 24.6 & 25.4 \\
7 & 95 & 90 & 79 & 25.2 & 25.6 & 25.6 \\
8 & 92 & 71 & 82 & 26.1 & 27.8 & 24.7 \\
9 & 97 & 89 & 86 & 24.8 & 23.9 & 23.3 \\
10 & 93 & 79 & 74 & 24.7 & 24.1 & 28.3 \\
11 & 96 & 97 & 69 & 25.3 & 25.9 & 28.0 \\
12 & 92 & 76 & 82 & 24.8 & 26.1 & 26.0 \\
13 & 85 & 99 & 69 & 26.0 & 23.0 & 30.7 \\
14 & 91 & 86 & 60 & 25.0 & 26.2 & 30.0 \\
15 & 88 & 90 & 84 & 24.5 & 25.4 & 24.0 \\
16 & 95 & 87 & 65 & 26.0 & 26.8 & 27.0 \\
17 & 78 & 91 & 62 & 24.5 & 24.3 & 27.7 \\
\hline
\end{tabular}

Remarks : EB $=$ East Banyumas; $\mathrm{WB}=$ West Banyumas; WP $=$ West Pekalongan Measurements were conducted daily at 11 a.m.

Table 2. Pearson Correlation Coefficients between Oleoresin Yield with Daily Temperature and Relative Humidity

\begin{tabular}{|c|c|c|}
\hline Sites & Temperature & Relative Humidity \\
\hline \multicolumn{3}{|c|}{ West Banyumas } \\
\hline SAEt1 & $0.68^{\star *}$ & $-0.63^{\star *}$ \\
\hline SAEt1 & $0.66^{\star *}$ & $-0.62^{* \star}$ \\
\hline SR4 & $0.68^{\star *}$ & $-0.64^{\star *}$ \\
\hline ETRAT & 0.25 & -0.22 \\
\hline Control & 0.29 \\
\hline \multicolumn{3}{|c|}{ East Banyumas } \\
\hline SAEt1 & 0.40 \\
\hline SAEt1 & 0.30 & -0.25 \\
\hline SR4 & 0.02 & $-0.62^{* *}$ \\
\hline ETRAT & 0.22 & -0.30 \\
\hline Control & 0.27 & -0.38 \\
\hline \multicolumn{3}{|c|}{ West Pekalongan } \\
\hline SAEt1 & -0.20 & -0.43 \\
\hline SAEt1 & -0.07 & 0.15 \\
\hline SR4 & -0.13 & 0.13 \\
\hline ETRAT & -0.12 & 0.10 \\
\hline Control & -0.07 & 0.27 \\
\hline
\end{tabular}

Notes: SAEt $1=$ mixture of $20 \%$ sulfuric acid $+1 \%$ Ethephon; SAEt $2=$ mixture of $20 \%$ sulfuric acid $+2 \%$ Ethephon; significance levels for correlation coefficients: ${ }^{* *} P<0.01$ and ${ }^{*} P<0.05$

The relationship between yield and temperature/relative humidity is displayed in Fig. 3 for SAEt1 in the West Banyumas and East Banyumas stands. In this case, higher temperature had produced higher oleoresin yield, but conversely for relative humidity for certain areas. The similar results was also observed in $P$. pinaster (Rodriguez-Garcia et al. 
2015), P. roxburghii (Sharma et al. 2018), and P. nigra (Gajsek et al. 2018). The higher temperature and lower humidity probably reduce the viscosity, thus enhancing the fluidity of oleoresin. The reason of various trend of the obtained correlations among the sites is unknown. It should be noted that the only once measurement of daily temperature and relative humidity might not give representative values. The measurement in different times (minimum, maximum, and average values) would give better description and correlation among parameters of the site e.g. (Gajsek et al. 2018; Sharma et al. 2018).
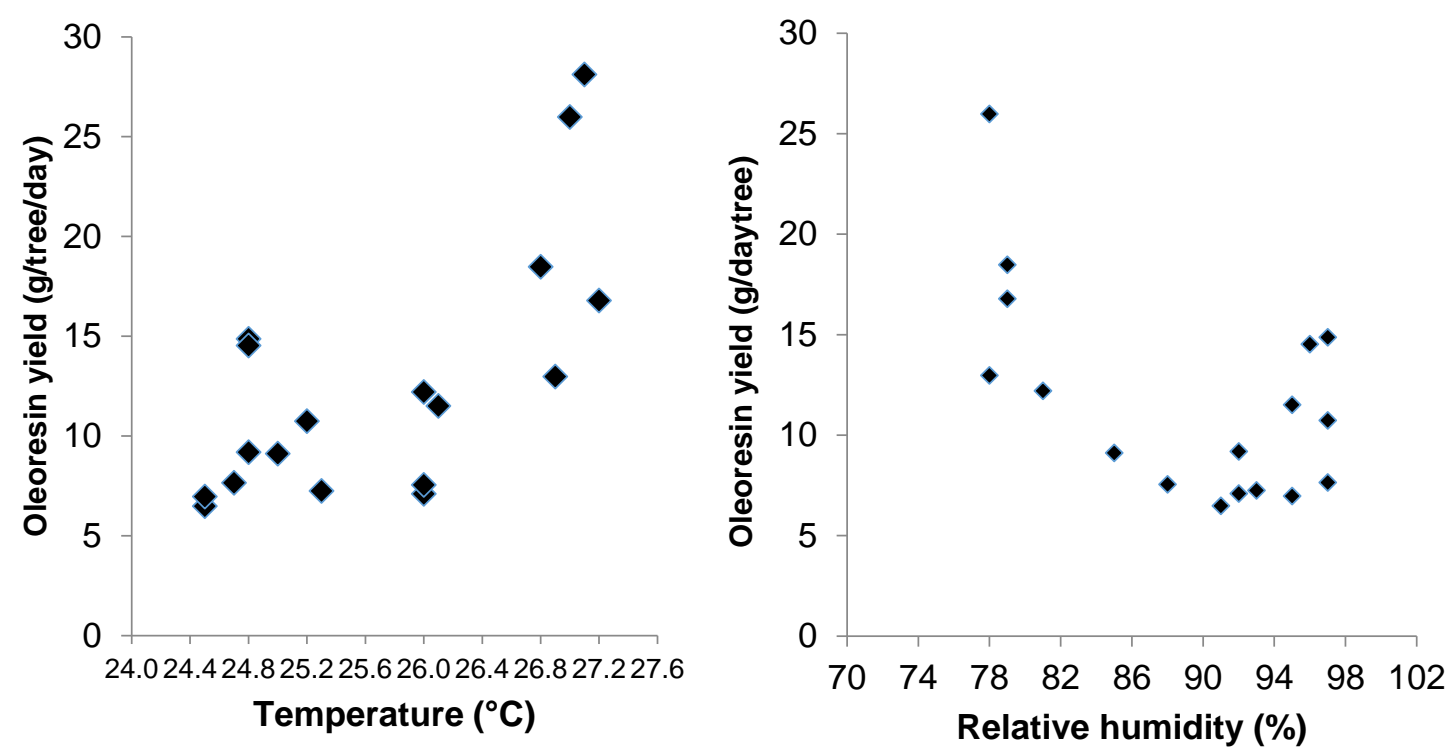

Fig. 3. The relations between oleoresin yield and daily temperature in West Banyumas stand (left) and relations between oleoresin yield relative humidity in East Banyumas stand with SAEt1 treatments

\section{Daily Oleoresin Yield}

The ANOVA analysis showed significant relation between the stimulants and sites $(\mathrm{P}<0.01)$. For the control trees, the highest DOY level $(10.31 \mathrm{~g} /$ tree/day $)$ was measured in the East Banyumas stand. However, for the Duncan test, there was no significant difference in the control trees and trees in West Banyumas and West Pekalongan stands in terms of DOY amount. The SAEt2, SAEt1, and SR4 stimulants strongly affected resin production compared to the control trees in all sites. Although SAEt2 treatment tended to give higher DOY than SAEt1, no statistical difference was found between them. Further, the highest production was obtained from SAEt 2 stimulated trees in West Pekalongan stand or equivalent to 2.85 times increase from their control trees. The lowest yield was recorded from SAEt1 stimulated trees in West Banyumas (1.69 times). For SR4, the highest amount (34.60 g/tree/day) was measured in East Banyumas stand, which increased yield 2.48 times. A significant difference between ETRAT stimulated trees and the control trees was observed only in the West Banyumas stand and that treatment increased resin production 1.58 times.

\section{The Interaction Between of Stimulants and Sites}

The available data on the average daily resin yield in $P$. merkusii per single tree is relatively limited. In the present experiment, the average DOY values per hole for control trees were 6.13 to $10.31 \mathrm{~g} /$ tree/day, whereas for stimulated trees were 8.89 to 24.60 
g/tree/day. The yield in this experiment might be lower as this study conducted in the rainy season. Earlier reports showed the lower production of resin yield of pine in a higher rainfall rate (Sharma and Lekha 2013; Sharma et al. 2018). By bark chipping method, some reports showed $P$. merkusii tapping yields was 4.15 to $8.90 \mathrm{~g} /$ tree/day for control trees and 13.50 to $23.00 \mathrm{~g} /$ tree/day for stimulated trees (sufuric acid, Ethephon, SR4, ETRAT) in East Banyumas stand (class age of 16-20 years) (Lukmandaru et. al. 2018). Further, Hadiyane et al. (2015) measured resin production (no stimulant treatment) equivalent to 4.72 to $7.58 \mathrm{~g} /$ tree/day in West Bandung stand (class age of 21 to 25 years) and Sukadaryati et al. (2014) obtained an amount equivalent to 1.34 to $4.70 \mathrm{~g} /$ tree/day from untreated and 2.96 to $13.8 \mathrm{~g} /$ tree/day from stimulated $P$. merkusii trees (sulfuric acid and ETRAT) in West Banyumas stand (11 years). This variation may be attributed to the variation on the sites, tapping method, and tree age.

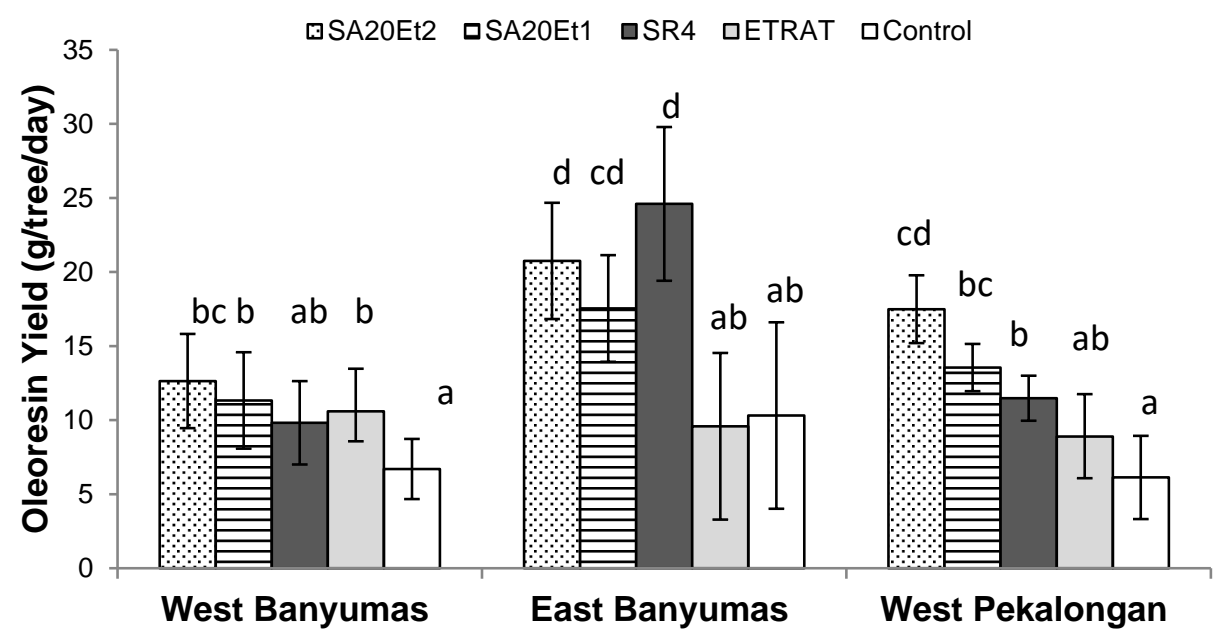

Fig. 4. The average daily oleoresin yield ( $n=20$ trees) exuded from one hole in different stimulants and sites. The same letters on the same graphic are not statistically different at $\mathrm{P}<$ 0.05 by Duncan's test.

The sulfuric acid tested in combination with Ethephon had a significant impact on resin production when compared with the controls (Fig. 4). The highest increase was observed in West Pekalongan (2.85 times), and the lowest was in West Banyumas (1.69 times) stands. The positive effect of Ethephon spraying could be a result of the induction of ethylene for stimulating oleoresin synthesis and/or traumatic resin canal differentiation (Wolter and Zinkel 1984). Furthermore, sulfuric acid increases yield by prolonging flow, preventing crystallization of resin acid and formation of tylosoids (Kossuth 1984). The combination indicated a synergistic effect that caused a high yield on the first day as well as prevented a significant reduction of resin production at the $2^{\text {nd }}$ or $3^{\text {rd }}$ day after wounding and stimulant spraying in comparison with untreated trees (Fig. 2). However, the comparatively high yield in East Banyumas after treatment with SR4 indicate that a synergistic effect was not intense as expected. This variation may attribute to the variation on the chemical composition of oleoresin, which their respective resin acids would react more intensively with the sulfuric acid alone in SR4 solution to prevent crystallization. In future studies, a more thorough analysis on the chemical composition of oleoresins will be helpful in explaining this finding. The low concentration of Ethephon in this experiment is of interest for cost reduction in resin tapping operations, but higher concentrations of 
sulfuric acid (> 20\%) might severely injure plants and pose higher risks for workers (Rodrigues et al. 2008). Unfortunately, no observation was made for wounded area after treatments to evaluate the damage in the wounds.

Trees treated with sulfuric acid and Ethephon mixture had equivalent or higher resin yields depending on the sites compared to those of trees exposed to the SR4 containing mainly sulfuric acid (Fig. 4). A similar result was obtained by Sharma and Lekha (2013) when investigating the effect of 10\% Ethephon and $20 \%$ sulfuric acid on $P$. roxburghii tapping. They reported that the effect of combined stimulants on resin yield was above those observed with only a single stimulant. Trees submitted to SAEt 2 showed an oleoresin yield statistically similar to those treated with SAEt1. It indicated that the number of formed resin canals was not always proportional to the concentration of Ethephon, particularly in a slight different concentration. Another possibility is the micro-climate variables (temperature, relative humidity, rainfall, etc.) did not affect considerably the changes in secretory structures after treatment with the two concentrations (RodriguezGarcia et. al. 2018).

The SR4 containing mainly sulfuric acid (unknown concentration) and other additives affected the yield mostly in the East Banyumas stand (Fig. 4). This result is in agreement with the findings of Sumantri and Endom (1989) on P. merkusii tapped with CAS (Indonesian: cairan asam sulfat/ sulfuric acid liquid) stimulant (containing mostly sulfuric acid). The highest daily oleoresin production they obtained was $12.72 \mathrm{~g} /$ tree/day in contrast to the yield of the control tree that ranged from 3.13 to $6.48 \mathrm{~g} /$ tree/day. The overall results of ETRAT based on ethylene and citric acid were ineffective in inducing resin production. The limited effect of ETRAT on oleoresin induction in the present experiments may have been related to the weak acidic nature of citric acid compared to sulfuric acid in maintaining resin flow. This result is consistent with the research described by Sukadaryati and Dulsalam (2013), who found the increase of oleoresin production by various biostimulants, but the values were still lower than those of CAS stimulant. Sukadaryati et al. (2014) showed that various weak acidic biostimulants did not produce resin as much as sulfuric acid in $P$. merkusii tapping.

An unusual trend was noticed, that the highest yield level from ETRAT stimulated trees was obtained on the $13^{\text {th }}$ day or the $1^{\text {st }}$ day in the $3^{\text {rd }}$ period of wounding in West Banyumas (Fig. 2). Further, the considerable increase of resin production was only measured on the last day of observation ( $18^{\text {th }}$ day) in the SR4 stimulated trees from the East Banyumas stand. The reasons for some trees and stimulants in a certain stand producing considerably greater quantities of resin than others are still not entirely known. The higher yields in the third period may have been related to the release of stored oleoresin. In the previous works, it was found that oleoresin yields from $P$. merkusii vary depending on genetic factors (Leksono 1996; Siregar and Hatemer 2004; Susilowati et al. 2013). In addition, the differences in local environmental conditions would make it capable of producing more oleoresin, e.g., the water availability (Rodríguez-García et al. 2015) and photoperiod (Chae and Kieber 2005) during the rainy season, which was when this experiment was conducted.

This experiment showed that there was no single factor influenced significantly on resin yield (Fig. 4). It is likely that a complex interaction system exists among trees, stimulants, and environmental factors. It is thought that a higher altitude has lower temperature and higher relative humidity to cause a lower resin production. However, the results showed that the yield among the control trees did not significantly differ. Furthermore, resin production of stimulated trees from the low altitude of West Banyumas 
tended to give lower yields of resin. A different pattern, i.e., the increased production on the $17^{\text {th }}$ day for all stimulants, was observed only in West Pekalongan, suggesting that the altitude was not the only factor to affect resin production. In addition, daily relative humidity and temperature did not show similar responses in all sites (Table 2).

The differences in annual rainfall, tree age, sunlight intensity, and soil type could be the other factors for these differences. West Pekalongan has the lowest annual rainfall $(216 \mathrm{~mm})$, although it has the highest altitude $(1150 \mathrm{~m}$ asl). It was found that there was no significant correlation between DOY and temperature or relative humidity in all treatments from the West Pekalongan stand. In this experiment, unfortunately, the class age among the pine stands were different, particularly between West Pekalongan (26 to 30 years) and West Banyumas (36 to 40 years). Thus, direct comparisons might not generate expected results. Furthermore, this factor probably related to the comparatively low yield in the West Banyumas (Fig. 4), which have older trees. This is in line with the findings of Sudrajat $e t$ al. (2002) who observed that the decrease in oleoresin yield of stimulated P. merkusii with tree age (among 15, 18, and 24 years). However, a different trend was found by Sumadiwangsa et al. (1999) who measured the increase in oleoresin yield of $P$. merkusii with tree age (among 19, 24, and 34 years). Moreover, diameter and crown size of the tree and duration of the tapping period (dry/wet-season) also affect the yields obtained (Coppen and Hone 1995; Sudradjat et al. 2002). Previously, the number of living branching, number of living whorls, tree height, bark thickness, and crown depth were found to have significant genetic correlation with resin yield of Pinus massoniana (Liu et al. 2013). The possible correlation of those parameters are not discussed within the scope of this paper but is worthy of further report. Other factors that should be considered and might help explain this difference are soil type (Samanta et al. 2012), tree age (Sudradjat et al. 2002), and silvicultural regime (Moulalis 1981). It should not be forgotten that the short duration of oleoresin production might not be enough to evaluate the effect of stimulant chemicals on different altitudes. Therefore, more homogenous samplings and longer duration of observation should be considered to answer those possibilities in subsequent works.

\section{CONCLUSIONS}

1. Oleoresin yield is significantly affected by interaction between stimulating agents and site with different latitudes. The SAEt2 and SAEt1 treatments gave a comparative high oleoresin production and are attractive as alternative stimulants to substitute the currently used stimulants.

2. The daily oleoresin yield exhibited positive significant correlation coefficient with daily temperature in West Banyumas site and negative correlation with daily humidity values in West Banyumas and East Banyumas sites.

\section{ACKNOWLEDGMENTS}

This research was financed by the Regional Division Unit I Perhutani and PMDSU Grant 2018 (Ministry of Research-Technology and Higher Education of the Republic of Indonesia). The authors also thank student enumerators for helping with data collection 
and the Administrators (West Pekalongan, East Banyumas, and West Banyumas) of the Perhutani Enterprise for providing observation sites.

\section{REFERENCES CITED}

Bhardwaj, P., Sharma, K.R., and Khosla. P.K. (2017). "Variation in resin ducts and yield in chir pine population." Int. J. Pharm. Sci. Res. 8(5), 2213-17. DOI:

10.13040/IJPSR.0975-8232.8(5).2213-17.

Chae, H. S., and Kieber, J. J. (2005). "Eto brute? Role of ACS turnover in regulating ethylene biosynthesis," Trends Plant Sci. 10(6), 291-296. DOI: 10.1016/j.tplants.2005.04.006

Coppen, J. J., and Hone, G. A. (1995). "Raw materials and inputs," in: Gum Naval Stores: Turpentine and Rosin from Pine Resin, FAO, Rome, Italy, pp. 17-22.

Darmastuti, I. N., Santosa, G., and Matangaran, J. R. (2016). "Penyempurnaan teknik penyadapan resin pinus dengan metode kuakan [Improvement of pine resin tapping with quare method]," J. Penelit. Hasil Hutan 34(1), 23-32. (In Indonesian) DOI: 10.20886/jphh.2016.34.1.23-32

Gajšek, D., Brecelj, M., Jarni, K., and Brus, R. (2018). "Resin yield of Pinus nigra and Pinus sylvestris in the Slovenian karst," Acta Silvae et Ligni 115, 21-28. DOI: 10.20315/Aset.115.2

Hadiyane, A., Sulistyawati, E., Asharina, W. P., and Dungani, R. (2015). “A study on production of resin from Pinus merkusii Jungh. et De Vriese in the Bosscha Observatory stand, West Java-Indonesia," Asian J. Plant Sci. 14(2), 89-93. DOI: 10.3923/ajps.2015.89.93

Hendromono, Y., Heryati, and Mindawati, N. (2006). Teknik Silvikultur Hutan Industri [Silvicultural Techniques of Industrial Plantation Forest], Pusat Penelitian dan Pengembangan Hutan Tanaman, Bogor, Indonesia, pp. 41-44. (In Indonesian)

Kossuth, S. V. (1984). Multipurpose Slash Pine: Genetics and Physiology of Gum Naval Stores Production (GTR/NE-90), U.S. Department of Agriculture Forest Products Laboratory, Madison, WI, USA.

Leksono, B. (1996). Heritabilitas dan perolehan genetik produksi getah, diameter batang, bentuk batang dan percabangan. Pinus merkusii Jungh et de Vries. [Heritability and genetic gain of oeloresin production, stem diameter, stem shape, and branching].' Bull. Kehutanan 11(suppl 2), 223-236. (in Indonesian)

Lempang, M. (2017). "Studi penyadapan getah pinus cara bor dengan stimulan $\mathrm{H}_{2} \mathrm{SO}_{4}$ [Study of pine resin tapping by drilling using $\mathrm{H}_{2} \mathrm{SO}_{4}$ stimulant]," J. Penelit. Hasil Hutan 35(3), 221-230. (In Indonesian) DOI: 10.20886/jphh.2017.35.3.221-230

Liu, Q., Zhou, Z., Fan, H., and Liu, Y. (2013). "Genetic variation and correlation among resin yield, growth, and morphologic traits of Pinus massoniana. "Silvae Genet. 62(12), 38-43. DOI: 10.1515/sg-2013-0005

Lukmandaru, G., Sunarta, S., Listyanto, T., Kasmudjo, Pujiarti, R., and Widyorini, R. (2018). "Evaluasi terhadap stimulan Ethephon dalam penyadapan Pinus merkusii

[Evaluation on Ethephon stimulant to Pinus merkusii tapping]," J. Ilmu Teknol. Kayu Tropis 16(2), 194-206. (In Indonesian)

Mergen, E., Hoekstra, P., and Echols, R.M. (1955). "Genetic control of oleoresin yield and viscosity in slash pine." For. Sci. 1(1), 19-30. DOI: 10.1093/forestscience/1.1.9 
Moulalis, D. (1981). "Variation in resin production of Aleppo pine in KassandraChalkidiki," Ann. Regional Sci. 19, 467-488.

Perhutani (2017). "Mengubah Budaya Kerja Menguatkan Usaha - Laporan Tahunan 2016 [Changing the Work Culture Strengthens the Business - Annual Report 2016], Perhutani, Jakarta, Indonesia.

Perhutani (2018). Ketekunan untuk Terus Tumbuh dan Berkembang - Laporan Tahunan 2017 [Persistence to Growing Up - Annual Report 2017], Perhutani, Jakarta, Indonesia.

Rodríguez-García, A., Martín, J. A., López, R., Mutke, S., Pinillos, F., and Gil, L. (2015). "Influence of climate variables on resin yield and secretory structures in tapped Pinus pinaster Ait. in central Spain," Agric. For. Meteorol. 202, 83-93. DOI: 10.1016/j.agrformet.2014.11.023

Rodrigues, K. C. S., Azevedo, P. C. N., Sobreiro, L. E., Pelissari, P., and Fett-Neto, A. G. (2008). "Oleoresin yield of Pinus elliottii plantations in a subtropical climate: Effect of tree diameter, wound shape and concentration of active adjuvants in resin stimulating paste," Ind. Crop. Prod. 27(3), 322-327. DOI:

10.1016/j.indcrop.2007.11.010

Samanta, J. N., Saravanan, R., Gajbhiye, N. A., and Mandal, K. (2012). "Growth, photosynthetic competence and oleo-gum resin production of guggal (Commiphora wightii) across soil moisture and nitrogen gradient," J. Trop. For. Sci. 24(4), 538-545.

Sharma, K. R., Kumar, R., Dutt, B., and Attri, V. (2018). "Effect of morphological and environmental factors on oleoresin yield in Pinus Roxburghii Sargent." Bull. Env. Pharmacol. Life Sci. 7 [SPL1], 75-78.

Sharma, K. R., and Lekha, C. (2013). "Tapping of Pinus roxburghii (chir pine) for oleoresin in Himachal Pradesh, India," Adv. Forestry Lett. 2(3), 51-55.

She, F., Zhu, D., Kong, L., Wang, J., Ana, F., and Lin, W. (2013). "Ultrasound-assisted tapping of latex from Para rubber tree Hevea brasiliensis," Ind. Crop. Prod. 50, 803808. DOI: 10.1016/j.indcrop.2013.08.065

Siregar, I.Z. and Hattemer, H.H. (2004). "Patterns of. genetic structure and variation of merkusi pine. (Pinus merkusii) in Indonesia." J. Trop. For. Sci. 16(2), 160-172.

Sudradjat, R., Setyawan, D., and Sumadiwangsa, S. (2002). "Pengaruh diameter pohon, umur dan kadar stimulan terhadap produktivitas getah [The effect of pine trees (Pinus merkusii Jungh. et De Vries) diameter, ages, and dosages of stimulant on the productivity of their exudates]," J. Penelit. Hasil Hutan 20(2), 143-158. (In Indonesian)

Sukadaryati, S., and Dulsalam, D. (2013). “Teknik penyadapan pinus untuk peningkatan produksi melalui stimulan hayati [The techniques of tapping pine to enhance its gum production using biostimulant agents," J. Penelit. Hasil Hutan 31(3), 221-227. (In Indonesian) DOI: 10.20886/jphh.2013.31.3.221-227

Sukadaryati, S., Santosa, G., Pari, G., Nurrochmat, D. R., and Hardjanto, H. (2014). "Penggunaan stimulan dalam penyadapan pinus [The use of stimulants on the pine tapping]," J. Penelit. Hasil Hutan 32(4), 329-340. (In Indonesian) DOI: 10.20886/jphh.2014.32.4.329-340

Sumadiwangsa, S., Lestari, N.H., Bratamiharja, S. (1999). "Pengaruh kadar stimulan dan penutupan luka sadap pada penyadapan tusam [The effect of stimulant cocentration and tapping wound closure on tusam tapping]," Duta Rimba September, 35-38. (in Indonesian) 
Sumantri, I., and Endom, W. (1989). "Penyadapan getah Pinus merkusii dengan menggunakan beberapa pola sadap dan tingkat konsentrasi zat perangsang [Resin tapping on Pinus merkusii using various tapping patterns and stimulant concentration levels]," J. Penelit. Hasil Hutan 6(3), 152-159. (In Indonesian)

Susilowati, A., Siregar, I.Z., Supriyanto, Wahyudi, I., and Corryanti. (2013). "Genetic variation, heritability and correlation between resin production character of Pinus merkusii high resin yielder (Hry)," Biotropia 20(2), 122-133.

DOI:10.11598/btb.2013.20.2.257

Tadesse, W., Nanos, N., Aufion, F.J., Alia, R., and Gil, L. (2001). "Evaluation of high resin yielders of Pinus pinaster Ait.," For. Genet. 8(4), 271-278.

Vasishth, A., and Guleria, V. (2017). "Standardized gum tapping techniques to maximize yield from high-value Indian tree, Sterculia urens," J. Forestry Res. 28(3), 615-619. DOI: $10.1007 / \mathrm{s} 11676-016-0315-1$

Wolter, K. E., and Zinkel, D. F. (1984). "Observations on the physiological mechanisms and chemical constituents of induced oleoresin synthesis in Pinus resinosa," Can. J. Forest Res. 14(3), 452-458. DOI: 10.1139/x84-080

Article submitted: October 4, 2019; Peer review completed: April 18, 2020; Revised version received and accepted: November 3, 2020; Published: November 11, 2020.

DOI: 10.15376/biores.16.1.163-175 